\title{
Short communication: Genetic parameters of milking temperament and milking speed in Canadian Holsteins
}

\author{
A. Sewalem, ${ }^{*}{ }^{1}$ F. Miglior, ${ }^{\star} \dagger$ and G. J. Kistemaker $†$ \\ *Guelph Food Research Centre, Agriculture and Agri-Food Canada, Guelph, Ontario, Canada, N1G 5C9 \\ †Canadian Dairy Network, Guelph, Ontario, Canada, N1K $1 E 5$
}

\begin{abstract}
The objectives of this study were to estimate genetic parameters of milking temperament (MT) and milking speed (MS) in Canadian Holsteins and to examine associations of bull proofs of MT and MS with other economically important traits. First-lactation data consisted of 1,940,092 and 2,620,175 cows for MT and MS, respectively. Milking temperament and MS were recorded on a scale from 1 to 5 from very nervous to very calm and from very slow to very fast, respectively. The linear animal model included the fixed effects of herd-year-season of calving, stage of lactation, age at first calving, and the random effects of animal and residual. Both single-trait and bivariate analyses were carried out to estimate genetic parameters of MT and MS. For genetic parameter estimation, 20,000 records from randomly selected herds were used. However, for breeding value estimation, all records were included. Heritability values were 0.128 and 0.139 for MT and MS, respectively. The genetic correlation between MT and MS was 0.247. Analysis of bull proof correlation of MT and MS with other traits indicated that these traits were lowly correlated with a wide range of traits such as production, reproduction, conformation, and auxiliary traits.
\end{abstract}

Key words: milking temperament, milking speed, genetic parameter

In dairy cattle production, most research has focused mainly on production, which represents only one component contributing to overall efficiency and profitability. In a review of national selection indices in several countries, Miglior et al. (2005) indicated that the importance of traits other than production in dairy cattle breeding programs has dramatically increased in the last $10 \mathrm{yr}$. However, for some of these traits, including milking temperament (MT) and milking speed (MS), little or no attention has been given in genetic selection

Received May 26, 2010.

Accepted September 17, 2010.

${ }^{1}$ Corresponding author: Asheber.sewalem@agr.gc.ca programs. Milking temperament can be defined in terms of milking behavior, ease of handling, or aggressiveness at feeding. Milking speed is also an important trait, in that a cow that milks out slowly may disrupt the flow of cows through the milking parlor. In Canada, MT and MS have been recorded for several years by milk recording agencies. Moreover, several reports have shown that they have been a factor for dairy cow disposal to an amount up to 2\% (Burnside et al., 1971; Westell et al., 1982; PATLQ, 1999; CDN, 2009). Although MT can be considered a trait of importance, especially in herds with automated milking systems, relatively little work has been done to evaluate the genetic component of such a behavioral trait and its relationship with other traits such as production, type, and other auxiliary traits. Heritability estimates of MT in the literature range from 0.05 to 0.08 (Hayes, 1998; Sewalem et al., 2002) for Canadian Holsteins. Moreover, Cue et al. (1996) reported a heritability estimate of 0.14 for shed temperament in New Zealand Holsteins. For MS in Canada, the first genetic parameters for this trait were estimated by Meyer and Burnside (1987) and they reported a heritability estimate of 0.21 . More recently, Wiggans et al. (2007) reported a heritability value of 0.22 for MS in US Brown Swiss. Sørensen et al. (2000) estimated heritability of values of $0.35,0.27$, and 0.17 for Danish Red, Danish Holstein, and Danish Jersey breeds, respectively. Dodenhoff and Emmerling (2009) estimated test-day heritability for average flow rate from 0.21 to 0.40 , for different lactations. To date, the literature contains no estimates of genetic correlation between MS and MT. The main objectives of this study were (a) to estimate the genetic parameters for MT and MS in Canadian Holsteins using recent data; (b) to estimate the genetic relationship between the 2 traits; and (c) to assess the relationship between bull EBV for MT and MS and EBV of other traits of economic importance in Canada.

Milking temperament and MS data were obtained from first-lactation records extracted for the August 2009 genetic evaluation at Canadian Dairy Network (Guelph, ON, Canada). Within the first 6 mo in lactation, each cow was evaluated by DHI field staff at 
Table 1. Description and frequency of milking temperament and milking speed data

\begin{tabular}{llr}
\hline Score & Description & $\%$ \\
\hline Milking temperament & & \\
1 & Very nervous & 1.45 \\
2 & Nervous & 9.80 \\
3 & Average & 49.20 \\
4 & Calm & 35.43 \\
5 & Very calm & 4.13 \\
Milking speed & & \\
1 & Very slow & 2.11 \\
2 & Slow & 11.31 \\
3 & Average & 60.04 \\
4 & Fast & 24.43 \\
5 & Very fast & 2.11 \\
\hline
\end{tabular}

the time of milking for their MT and MS and given a subjective score based on a 5-point linear scale (MT: 1 $=$ very nervous, $2=$ nervous, $3=$ average, $4=$ calm, and $5=$ very calm; MS: $1=$ very slow, $2=$ slow, $3=$ average, $4=$ fast, and $5=$ very fast). Description and frequency of MT and MS data are reported in Table 1. Scoring of MT and MS was done only once per cow during the first 6 mo of the first lactation. Test-day milk yield, at the time of scoring these traits, ranged from 0.5 to $60.26 \mathrm{~kg}$ with mean value of $30.33 \pm 6.10 \mathrm{~kg}$. The variance components were estimated from a single-trait and 2-trait linear animal model that included random effects of animal and residual. Data were analyzed using the following model:

$$
\mathbf{y}=\mathbf{X b}+\mathbf{Z a}+\mathbf{e},
$$

where $\mathbf{y}$ is the vector of the observations for MT or MS; $\mathbf{X}$ and $\mathbf{Z}$ are the incidence matrices relating the observations to the fixed and random effects, respectively; $\mathbf{b}$ is a vector that contains the fixed effects (including herd-year, season of calving, stage of lactation and age at first calving); $\mathbf{a}$ is the vector of random additive genetic effects of animal; and $\mathbf{e}$ is the vector of random residual effect. Effect of year of calving was for years 1993 to 2009 for MT and from 1983 to 2009 for MS.
Seasons of calving were January-March, April-June, July-September, and October-December). Seven stages of lactation were defined ( $1=0$ DIM; $2=1-32$ DIM; $3=33-62$ DIM; $4=63-92$ DIM; $5=93-122$ DIM; 6 $=123-152$ DIM; $7=153-180$ DIM) and age at first calving ranged from 18 to 36 mo. The expectations and assumed variances are $\mathbf{E}(\mathbf{y})=\mathbf{X b} ; \mathbf{E}(\mathbf{a})=\mathbf{E}(\mathbf{e})=0$; $\mathbf{V}(\mathbf{a})=\mathbf{G} ; \mathbf{V}(\mathbf{e})=\mathbf{R} ; \operatorname{cov}\left(\mathbf{a}, \mathbf{e}^{\prime}\right)=0 ;$ and $\mathbf{V}(\mathbf{y})=$ $\mathbf{Z G Z}$ ' $+\mathbf{R}$, where $\mathbf{G}$ is the direct product between the numerator relationship matrix (A) for animal and the matrix of genetic variance and covariances, $\mathbf{G}=$ $\mathbf{A} \otimes \mathbf{G}_{\mathbf{0}} ; \mathbf{R}$ is the direct product between an identity matrix of order of the number of observations and the matrix of error variances and covariances $(\mathbf{R}=\mathbf{I} \otimes$ $\mathbf{R}_{\mathbf{0}}$ ). The analysis was done using 20,000 records from randomly selected herds. Herds that showed zero or little coefficient of variation with respect to these traits were excluded from the analysis. A total of 158 herds were selected and with minimum and maximum herd size of 5 and 729, respectively. A 2-trait animal model, with the same fixed effects as above, was also used to estimate the genetic correlation between MT and MS. (Co)variance components were estimated using a DMU software package with an expectation-maximization (EM)-REML algorithm for the analysis of multivariate mixed models (Madsen and Jensen, 2006). The package estimated covariance of random effects by using the DMU EM-REML algorithm (average information, but combining average information and EM if an update goes outside the parameter space).

Estimated genetic parameters from this study were used to estimate breeding values for MT and MS using a single-trait animal model. For breeding value estimation, records included 1,940,092 cows that calved from 1993 to 2009 for MT and 2,620,175 cows that calved from 1983 to 2009 for MS. The numbers of sires included in the evaluation were 28,837 and 41,140 for MT and MS, respectively. Subsequently, correlations between bull EBV for MT and EBV for other available traits, as routinely estimated by Canadian Dairy Network, were estimated. Estimated breeding values for

Table 2. Estimate of genetic parameters for milking temperament (MT) and milking speed (MS) from a single-trait and a bivariate analysis (MT $+\mathrm{MS})$

\begin{tabular}{lccccc}
\hline & \multicolumn{3}{c}{ MT } & & \multicolumn{3}{c}{ MS } \\
\cline { 2 - 3 } \cline { 5 - 6 } $\begin{array}{l}\text { Source of } \\
\text { variation }\end{array}$ & $\begin{array}{c}\text { Single } \\
\text { trait }\end{array}$ & Bivariate & & $\begin{array}{c}\text { Single } \\
\text { trait }\end{array}$ & Bivariate \\
\hline Animal & 0.0042 & 0.0061 & & 0.0003 & 0.00045 \\
Residual & 0.0285 & 0.024 & & 0.0018 & 0.0027 \\
Total & 0.0327 & 0.0301 & & 0.0021 & 0.00315 \\
Heritability & 0.13 & 0.20 & & 0.14 & 0.1429 \\
SE $(\mathrm{h})^{1}$ & 0.014 & 0.019 & & 0.012 & 0.015 \\
\hline
\end{tabular}

${ }^{1} \mathrm{SE}(\mathrm{h})=$ standard error of heritability. 
Table 3. Correlations between bull EBV for milking temperament and conformation, reproduction, and auxiliary traits in Canadian Holsteins

\begin{tabular}{|c|c|}
\hline Trait & Value \\
\hline \multicolumn{2}{|l|}{ Conformation traits } \\
\hline Loin strength & $0.133^{* * *}$ \\
\hline Rump & $0.106^{* * *}$ \\
\hline Angularity & $0.066^{* * *}$ \\
\hline Dairy strength & $0.061 * * *$ \\
\hline Rump angle & $0.058 * * *$ \\
\hline Stature & $0.057 * * *$ \\
\hline Height at front end & $0.056 * * *$ \\
\hline Heel depth & $-0.053^{* * *}$ \\
\hline Foot angle & $-0.049 * * *$ \\
\hline Overall conformation & $0.042^{* * *}$ \\
\hline Height & $0.026^{*}$ \\
\hline Front teat placement & $-0.031^{*}$ \\
\hline Bone quality & $0.019^{*}$ \\
\hline Teat length & $0.037^{* *}$ \\
\hline Rear udder attachment width & $0.038^{*}$ \\
\hline \multicolumn{2}{|l|}{ Reproduction traits } \\
\hline Calving ease cow & $-0.111^{* * *}$ \\
\hline Calf size cow & $-0.110^{* * *}$ \\
\hline Calf size heifer & $-0.101^{* * *}$ \\
\hline Direct calf size cow & $-0.086^{* * *}$ \\
\hline Direct calving ease cow & $-0.084^{* * *}$ \\
\hline Calving ease heifer & $-0.077^{* * *}$ \\
\hline Direct calving ease heifer & $-0.072^{* * *}$ \\
\hline Direct calf size heifer & $-0.070^{* * *}$ \\
\hline Calving ability & $-0.069^{* * *}$ \\
\hline Calving to first service & $-0.066^{* * *}$ \\
\hline Direct calving ability & $-0.062^{* * *}$ \\
\hline Direct calf survival heifer & $-0.030^{* *}$ \\
\hline Days open & $-0.028^{*}$ \\
\hline Age at first service & $0.026^{*}$ \\
\hline Direct calf survival cow & $-0.039^{*}$ \\
\hline \multicolumn{2}{|l|}{ Auxiliary traits } \\
\hline Somatic cell score & $0.190 * * *$ \\
\hline Milking speed & $0.150^{* * *}$ \\
\hline Persistency & $-0.068^{* * *}$ \\
\hline
\end{tabular}

${ }^{*} P<0.1 ;{ }^{*} P P<0.05 ; * * * P<0.01$.

MT from a total of 4,109 for MT and 4,148 for MS with official Lifetime Profit Index, respectively, were used. These bulls were born from 1995 through 2005 and have at least 10 daughters with records of MT or MS. Their relative breeding values were averaged by year of birth to estimate the genetic trend over time. Different sets of data with the same number of observations were used to estimate genetic parameters and results were consistent across the different data sets.

The estimated additive genetic and residual variances from single-trait and bivariate analyses for MT and MS are presented in Table 2 . The heritability values were $0.128 \pm 0.014$ and $0.139 \pm 0.012$ for MT and MS, respectively. These estimates are within the range of the literature values. The genetic correlation between MT and MS was $0.247 \pm 0.075$ and the phenotypic correlation between these traits was 0.10. Although the heritability value did not change for MS from the bivariate analysis, MT benefited from the bivariate analysis in that it showed a significant improvement of heritability value (from 0.13 to 0.20 ). The heritability estimate for MS found in this study is lower than those estimate reported by Meyer and Burnside (1987) who reported a heritability value of 0.21 for Canadian Holsteins. The authors used data recorded between 1982 and 1985 under Agriculture Canada's Record Performance Milk recording scheme, which is different from the current type of recording system. A heritability value for MS of 0.11 was reported by Zwald et al. (2005) and 0.10 by Rensing and Ruten (2005) based on single animal observations, whereas it was 0.15 in a study by Boettcher et al. (1998). These estimates vary perhaps because of differences in the data used and in the analytical methods applied.

To facilitate the interpretation of bull EBV for MT and MS, genetic evaluation was expressed as a relative breeding value with a mean of 100 and standard devia-

Table 4. Correlations between bull EBV for milking speed and conformation, reproduction, and auxiliary traits in Canadian Holsteins

\begin{tabular}{|c|c|}
\hline Trait & Value \\
\hline \multicolumn{2}{|l|}{ Conformation traits } \\
\hline Udder depth & $0.239^{* * *}$ \\
\hline Udder texture & $0.229 * * *$ \\
\hline Mammary system & $0.224^{* * *}$ \\
\hline Teat length & $-0.205^{* * *}$ \\
\hline Height at front end & $0.194^{* * *}$ \\
\hline Overall conformation & $0.172^{* * *}$ \\
\hline Median suspensory & $0.128^{* * *}$ \\
\hline Bone quality & $0.122^{* * *}$ \\
\hline Rear udder attachment height & $0.114^{* * *}$ \\
\hline Angularity & $0.103^{* * *}$ \\
\hline Rear leg side view & $0.082^{* * *}$ \\
\hline Pin width & $0.073^{* * *}$ \\
\hline Front teat placement & $0.068^{* * *}$ \\
\hline Rear teat placement & $0.068^{* * *}$ \\
\hline Feet and legs & $0.061^{* * *}$ \\
\hline Dairy strength & $0.059^{* * *}$ \\
\hline \multicolumn{2}{|l|}{ Reproduction traits } \\
\hline Calf size cow & $-0.074^{* *}$ \\
\hline First service to conception cow & $-0.068^{* * *}$ \\
\hline Days open & $-0.065^{* * *}$ \\
\hline Number of services cow & $-0.062^{* * *}$ \\
\hline Calf survival heifer & $0.055^{* * *}$ \\
\hline Nonreturn rate cow & $-0.055^{* * *}$ \\
\hline Calf size heifer & $-0.051^{* * *}$ \\
\hline Direct calf size heifer & $-0.044 * * *$ \\
\hline Calving ease cow & $-0.041^{* * *}$ \\
\hline Number of services heifer & $-0.040^{* * *}$ \\
\hline First service to conception heifer & $-0.039^{* *}$ \\
\hline Calf survival cow & $0.035^{*}$ \\
\hline Age at first service heifer & $0.032^{*}$ \\
\hline Nonreturn rate heifer & $-0.030^{*}$ \\
\hline Gestation length heifer & $-0.030^{*}$ \\
\hline Calving to first service cow & $-0.028^{*}$ \\
\hline \multicolumn{2}{|l|}{ Auxiliary traits } \\
\hline Somatic cell score & $0.246^{* * *}$ \\
\hline Herd life & $0.094^{* * *}$ \\
\hline Milking temperament & $0.150^{* * *}$ \\
\hline
\end{tabular}

${ }^{*} P<0.1 ;{ }^{* *} P<0.05 ;{ }^{* * *} P<0.01$. 


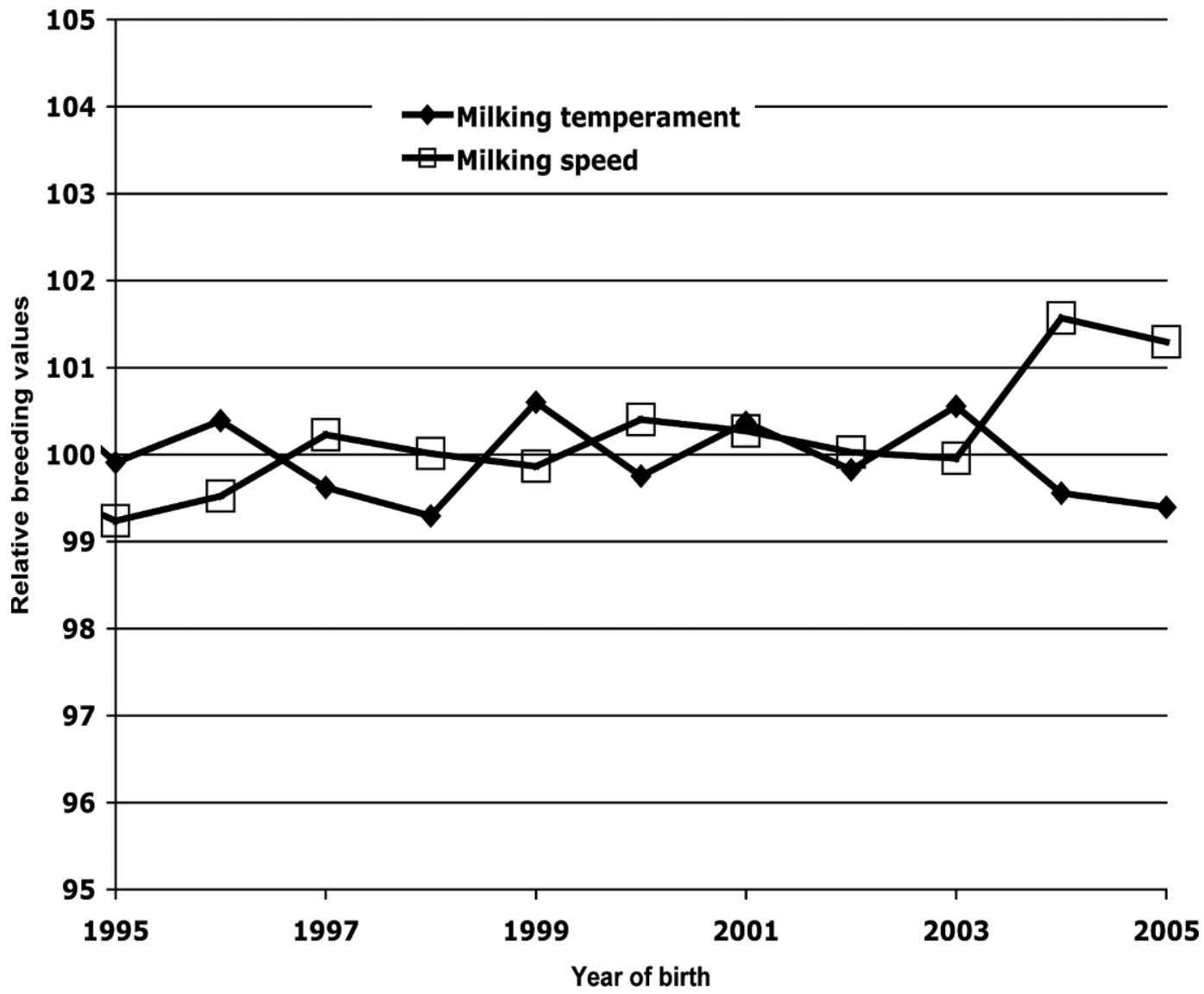

Figure 1. Genetic trend expressed as relative breeding value for milking temperament and milking speed in Canadian Holsteins.

tion of 5. In the Holstein breed, 4,109 and 4,148 bulls born from 1995 through 2009 received an official EBV for MT and MS, respectively, as well as for production and type traits. Simple correlations among bull EBV can be useful for providing a basic understanding of various trait interrelationships.

Proof correlations between MT and MS with firstlactation production traits such as milk, fat, and protein yields were generally weak and only significant $(P$ $<0.05)$ for fat yield. In this study a separate analysis (not shown), was carried out to estimate the genetic correlation between milk yield and milking speed and the estimate was not significantly different from zero $(-0.05 \pm 0.086)$. Tables 3 and 4 report the proof correlations between MT and MS with a series of reproduction traits. Most correlations were low and close to zero.

Tables 3 and 4 report the proof correlations between MT and MS with conformation traits. Most of the proof correlations between MT and conformation traits were also close to zero, with the exception of overall rump (0.106) and loin strength (0.133). As with MT, most correlations between conformation traits and MS were close to zero, with the exception of udder depth (0.239), udder texture (0.229), teat length $(-0.205)$, median suspensory (0.128), overall conformation (0.172), overall mammary system (0.224), front angle (0.194), and angularity (0.103). Tables 3 and 4 report also the proof correlations between MT and MS with additional functional traits, such as herd life (positively correlated with MS; 0.094) and SCS, undesirably positively correlated with both MT (0.190) and MS (0.246), the latter being the strongest EBV correlation of any trait with MS. Finally, Figure 1 shows the genetic trends of MT and MS for official base bulls born from 1995 to 2005 . The figure showed that the genetic trend for MT and MS has increased very little and irregularly over the years.

The use of a linear model for categorical data is considered to be a relatively robust approximation when the numbers of observations are proportional across the different categories. However, because of the distribu- 
tion of the data used in this analysis, the assumption of normality might be violated and, therefore, it might be of interest to use a threshold model in the future.

In conclusion, estimated genetic parameters for MT and MS were within the range of literature. The new genetic parameters estimated in this study have been officially implemented by the Canadian Dairy Network for the national genetic evaluation of MT and MS for all Canadian dairy breeding using a single-trait animal model. Correlations between bull EBV for MT and MS and with various reproduction, conformation, and auxiliary traits showed very low but significant relationships. The positive genetic correlation between MT and MS (0.247) suggests that cows with average or calm temperament during milking let down their milk quicker and have a reduced total milking time, whereas more nervous cows end up taking more time to milk.

\section{REFERENCES}

Boettcher, P. J., J. C. M. Dekkers, and B. W. Kolstad. 1998. Development of an udder health index for sire selection based on somatic cell score, udder conformation, and milking speed. J. Dairy Sci. 81:1157-1168.

Burnside, E. B., S. B. Kowalchuck, D. B. Lam-Broughton, and N. M. Macleod. 1971. Canadian dairy cow disposals I. Differences between breeds, lactation numbers and seasons. Can. J. Anim. Sci. $51: 75-83$.

CDN. 2009. Trends in Disposal Reasons 2009, CDN. http://www.cdn. ca/articles.php. Accessed Dec. 1, 2009.

Cue, R. I., B. L. Harris, and J. M. Rendel. 1996. Genetic parameters for traits other than production in purebred and crossbred New Zealand dairy cattle. Livest. Prod. Sci. 45:123-135.
Dodenhoff, J., and R. Emmerling. 2009. Genetic parameters for milkability from the first three lactations in Fleckvieh cows. Animal 3:329-335

Hayes, J. F. 1998. Heritability of temperament in Canadian Holsteins. Proc 6th World Congr. Genet. Appl. Livest. Prod. Armidale, Australia. Armidale, NSW, Australia. 23:391-394.

Madsen, P., and J. Jensen, 2006. DMU, a Package for Analyzing Multivariate Mixed Models. Version 6, release 4.6. Faculty of Agricultural Sciences (DJF), Department of Genetics and Biotechnology, Research Centre Foulum, Tjele, Denmark.

Meyer, K., and E. B. Burnside. 1987. Scope for a subjective assessment of milking speed. J. Dairy Sci. 70:1061-1068.

Miglior, F., B. L. Muir, and B. J. Van Doormaal. 2005. Selection indices in Holstein cattle of various countries. J. Dairy Sci. 88:12551263.

PATLQ. 1999. Rapport de production 1999 du le Programme d'analyse des troupeaux laitiers du Québec (PATLQ). Sainte-Annede-Bellevue, Québec, Canada. Page 50.

Rensing, S., and W. Ruten. 2005. Genetic evaluation for milking speed in German Holstein population using different traits in a multiple trait repeatability model. Interbull Bull. 33:163-166.

Sewalem, A., G. Kistemaker, and B. Van Doormaal. 2002. Bayesian inferences for milking temperament in Canadian Holsteins. Communication no. 20-04 in Proc. 7th World Congr. Genet. Appl. Livest. Prod., Montpellier, France.

Sørensen, M. K., J. Jensen, and L. G. Christensen. 2000. Udder conformation and mastitis resistance in Danish first-lactation cows: Heritabilities, genetic and environmental correlations. Acta Agric. Scand. Anim. Sci. 50:72-82.

Westell, R. A., E. B. Burnside, and L. R. Schaeffer. 1982. Evaluation of Canadian Holstein-Friesian sires on disposal reasons of their daughters. J. Dairy Sci. 65:2366-2372.

Wiggans, G. R., L. L. Thornton, R. R. Neitzel, and N. Gengler. 2007. Genetic evaluation of milking speed for Brown Swiss dairy cattle in the United States. J. Dairy Sci. 90:1021-1023.

Zwald, N. R., K. A. Weigel, Y. M. Chang, R. D. Welper, and J. S. Clay. 2005. Genetic evaluation of dairy sires for milking duration using electronically recorded milking times of their daughters. J. Dairy Sci. 88:1192-1198. 